\title{
SOCIAL MARKETING AS A MEANS FOR SOCIALIZING INDIVIDUAL INCOME TAX FOR MSMEs IN MALANG CITY
}

\author{
Arif Budi Prasetya, \\ Communication Science Dept. Brawijaya University \\ Malang, Indonesia \\ arif.budiprasetya@gmail.com,
Hanifa Maulani Ramadhan, Business Dept. \\ hanifadzafira@gmail.com
}

\author{
Kartika Putri Kumalasari \\ Taxation Dept. \\ kartika.putri.kumalasari@gmail.com
}

\author{
Intan Prylia Rahmi, \\ Communication Science Dept, \\ intanprylia@gmail.com
}

\begin{abstract}
Improving the formation of tax administration capacity is indispensable since it may lead to the potentially unstable tax ratio in Indonesia in the next few years. The delivery of information to the taxpayer becomes essential in revamping the tax administration. In the area studied in Malang city, information asymmetry (imbalance) occurs for taxpayers of Individual Income Tax on MSMEs. There are four subdistricts and four types of businesses of 226 businesses but the tax compliance in the Malang city merely reaches $\mathbf{8 8 \%}$. Thus, it is necessary to identify the problems of socialization and the use of media that has been carried out and provide suggestions that can be utilized by the Regional Office of DJP East Java III using social media
\end{abstract}

\section{INTRODUCTION}

Socialization is a form of structured and directed message delivery to the public. From public communication perspective, public segmentation is a part of the targets to be achieved while socialization is considered as the campaign process since it requires a treatment of delivering message to the wider community. In general, the community that want to be reached and addressed possesses different mental and social dimensions, so the socialization technique is needed to achieve the efficiency. "Message efficiency can be boosted when subsetcommunities are prioritized based on the importance of those segments in achieving campaign goals as well as the receptivity that can be affected." (Berger, 2015: 603). The statement indicates that this aspect is important to be examined, because it covers important matters related to the needs of the approach through segmentation and socialization for target participants of individual income tax MSMEs in Malang City based on Government Regulation No. 46. Research findings revealed the importance of using more advanced technology in tax dissemination. In addition, there is also a need for synergy between the community and government in order to achieve the success of technological media based tax socialization for creating more effective form of communication by considering tax sector as one of the main sectors supporting national economy.

Keywords: Socialization of Individual Income Tax, Social Marketing, Tax Compliance, MSMEs

community, one of which is the service to the public. By prioritizing the effectiveness in conducting socialization, then the need for public services can be realized positively. It proves that theoretical literature review has a high correlation level with practical aspects.

In terms of practical aspect, the application of socialization in the public sector can be examined through what has been performed by Malang Regional Tax Office III. The level of tax obedience in Malang is still $88 \%$ in which the realization of Annual Tax Return (SPT) achieves 91,997 out of the target of 104,165 . So far, the overall tax revenue has reached $16.63 \%$ or IDR 4.34 trillion. Therefore, the revenues this year increased by $37 \%$ (bisnis.radarmalang, 2017) although Malang Regional Tax Office has been conducting direct and indirect education and service. Indirect education has been performed using newspapers, radio, social 
media and web sites. The selected newspapers are the newspapers that are often read by people in Malang city, namely Radar Malang. Radio used is also often monitored by the wider community of RRI and Cosmo. Similarly, the website of Directorate General of Taxation is currently on the top list of the most visited website in which its live chat facility enables the community and taxpayer to interact directly. However, the arising issue is whether or not the community and taxpayers are already aware of the information that has been submitted. This will be further investigated in this research on the evaluation of socialization on tax compliance.

Socialization conducted by Malang Regional Tax Office III is also targeting the MSMEs in Malang City. MSMEs have its own characteristics in the imposition of its taxation. In Government Regulation No. 46, MSMEs is subjected of its $1 \%$ turnover of, except the MSMEs that freeze their business, or nil. MSMEs data affected by Regulation No. 46 dynamically moves because there is a possibility that the business will thrive. If the business thrives, then it will be taxed at a later stage, otherwise it will be nil. Thus, monitoring the success of the socialization of MSMEs is challenging since the early identification of potential problems may be problematic due to the deficiency in documentation process. This topic will be discussed later in the discussion section. MSMEs are the driving principals of the Indonesian economy that has an important role in the business development. MSMEs have a quite strong business resilience compared with large-scale business operators. Referring to data from the Ministry of Cooperatives and MSMEs in 2013, the data obtained in 2012-2013 showed that MSME business unit increased by $10.29 \%$ while Business Entity only increased by $1.97 \%$ of the total number of businesses. MSMEs were able to absorb $43.87 \%$ labor while Business Entity was only able to absorb $12.27 \%$ of the total labor absorbed in 2012-2013. Currently, there are 10,116 MSMEs in Malang (CBS, 2016). These data indicate that, in the long term, it can be estimated that tax obtained from MSMEs will continue to increase.

Social marketing was born in the 1970s when Kotler \& Zaltman (1971) realized that marketing principles used to sell products to consumers could also sell ideas, attitudes, and behaviors. Kotler \& Andreasen (2002) states that social marketing seeks to influence social behaviors, not solely for marketer's benefit, but also for better behavior changes according to the target and benefit of the society at large. According to Kotler \& Roberto (1989), social marketing is a social change management technology that involves the design, implementation, and control of programs aimed at increasing acceptance of ideas or social practices in one or more target group adopters. Furthermore, social marketing uses concepts from market segmentation, consumer research, product development and testing, directional communication, facilitation, incentives, and exchange theory to maximize responses from target adopters. Actors promoting these activities seek to pursue the goals of change with the belief that they will contribute to the best interests of the individual or society.

A process that applies marketing principles and techniques to create, communicate, and deliver values in order to influence target audience behaviors that benefit society (as well as target audiences (Kotler, Lee, Rothschild.). The application of commercial marketing technologies to the analysis, planning, execution, and evaluation of programs design is to influence the voluntary behavior of target audiences in order to improve their personal welfare and that of their society. (Andreasen, 1995)

According to Lefebvre (2011), social marketing is the application of marketing principles and techniques to encourage social change or improvement, whether it involves public health issues, accident prevention, environmental issues, transportation demand management or other social needs. To spread this idea, the role of the media is very important. The concept of social marketing is needed in various aspects of social life and society, as well as in the taxation. So, this is a challenge for the tax actors and academia to provide solutions to the problems faced by the tax sector. By providing proper and effective socialization patterns, people will be more aware and concerned with tax. Obstacles that may be encountered in the socialization in Malang is the lack use of Internet as a means of socialization so that the conventional socialization pattern in the form of face to face and brochures or orally is still regarded as a fairly effective socialization pattern.

This article focuses on the description of media-based socialization performed by Malang Regional Tax Office III for the individual income tax on MSMEs in Malang, including the media used and the obstacles faced during the socialization. Secondly, this research describes the means which can be carried out by Directorate General of Taxation of East Java III in determining the segmentation and target participants of the socialization of individual income tax on MSMEs in Malang city. The unique facts of this research is that there are three background of interest from two faculties at Brawijaya University namely Faculty of 
Administrative Sciences and the Faculty of Social and Political Sciences. The incorporated interests are required in completing this research on Information Systems, Public Communications and Taxes. Tax science will not be able to evolve well without any study of public information and communication system. Secondly, it provides a different perspective for the study of marketing in government agencies especially, in this case, the Directorate General of Taxation in helping the compliance of taxpayer MSMEs in Malang where MSMEs in Malang City have various criteria of business and Taxpayers' perception. Thus, referring to these problems, the findings of this research has proved the importance of the use of more advanced technologies in tax socialization. In addition, there is also a need for synergy between the community and the government in order to achieve tax-based socialization of media technology so that it will create a more effective form of communication by considering that tax sector is one of main sector supporting the national economy.

\section{RESEARCH METHOD}

The study on Social Marketing: Socialization of individual income tax for MSMEs in Malang employed qualitative methods in order to answer the research problem on the implementation of excise policy and alternative socialization that can be given to the Regional Tax Office of East Java III in accordance with the scientific procedures (Keyton, 2006:2). Qualitative research method was utilized to deeply analyze social phenomenon and performed observation as complete as possible to gain a full understanding (Babbie 2014: 304). The design of this study is complemented by using case study to be able to explore the phenomena or case by using multiple stages tied to time and activity and gathering information in detail by using data collection procedures that vary according to the time specified (Creswell, 1994: 12) . The unit of analysis used is using the object of a situation in the Counseling Division of Information Service at the Customs Office of Regional Office I of East Java (Babbie, 2005: 96).

This study obtained the primary data by conducting interviews at the Counseling Division of Information Service and will be cascaded to find the main informant so that we used it purposefully (informant specified) (Creswell, 1994: 149) and also snowball sampling (Singleton, Jr. and Straits, 2005: 138) to find the key informants.

Data were collected using participatory observation and interviews to establish the closeness and trust between the researcher and the interviewee (Babbie,
2014: 325). Next, it will proceed with the coding, memoing (Babbie, 2014: 413), mapping concepts (theory) and connecting the coding pattern (Miles and Huberman, 1994: 71). Content analysis was utilized to identify the content correlation of one source and the others (Lofland; Snow; Anderson; and Lofland 2006:2). The qualitative data also needs to be verified by using internal and construct validity and its reliability (Creswell, 1994: 158) namely by using triangulation of sources and techniques.

\section{RESULT AND DISCUSSION}

a. Describing the socialization activities performed by Regional Tax Office of East Java III for Individual Income Tax on MSMEs in Malang City

One form of the socialization of Individual Income Tax on MSMEs in Malang conducted by the Regional Office is formally direct and indirect socialization. Direct socialization is formal in which Regional Tax Office of East Java III usually conducts socialization in the Regional Office itself or in cooperation with related agencies, institutions and agencies. Direct socialization conducted in the form of tax class of Individual Income Tax for MSMEs in the working area of the Regional Tax Office of East Java III. Furthermore, to gather taxpayers with the category of MSMEs, the Regional Tax Office of East Java III cooperates in activities held by the related government institutions.

When the related government institutions held an event with MSME as the participants, the regional tax office entered as a performer in one segment. Socialization of individual income tax for MSMEs undertaken will focus on making people to be aware, educate them, publish information on taxation, as well as the form of equal access. In addition to the related government agency such as the Office of Cooperatives, the Regional Tax Office also cooperates with the financial institution to conduct the socialization of Individual Income Tax for MSMEs. The similar strategy used by inserting the subject of the tax obligation of MSMEs among the main segments of the event of banking institutions as a lender of capital. The objective of the cooperation of the Regional Tax Office of East Java III with the agencies, institutions and related is attracting the participants of MSMEs to participate as a participant of taxation counseling. The tax counseling in the region of this tax office is sporadic aimed at increasing the awareness of 
SMEs on tax obligations related to government regulation (PP) 46.

Formal form of socialization also performed by the Regional Tax Office of East Java III is by publishing reading materials in the form of articles usually published in local newspapers such as Radar Malang. Another indirect formal socialization is the availability of printed leaflets of Government Regulation Number 46 placed in tax offices.

b. Describing the media used by Regional Tax Office of East Java III as a means of socialization for Individual Income Tax on MSMEs in Malang city

Media as a communication instrument is quite crucial. The use of proper media socialization can provide output in the form of complete information delivery and received by the target. Feedback to be obtained from the involvement of the media in the socialization process is that the participants can understand and know information that has been given. This study reveals that the Regional Tax Office of East Java III has used a variety of communication media for the socialization of individual income tax of MSMEs in Malang city including mass media both printed and electronic media. The printed media used for socialization is in the form of individual income tax articles in local newspapers on a regular basis, posters and leaflets about the general knowledge of Government Regulation Number 46 Year 2013. For electronic media, the socialization of individual income tax has been carried out by holding a routine talk show on the radio in Malang city. In addition, the the Regional Tax Office of East Java III also advertised tax service on radio. Furthermore, social media is utilized in its efforts to be closer with Taxpayers and also the public in general. The brief description of social media used is presented in the following Table 1:

Table 1. Description of Social Media used by Regional Tax Office of East Java III

\begin{tabular}{|l|l|}
\hline Social media & \multicolumn{1}{|c|}{ Description } \\
\hline Twitter & $\begin{array}{l}\text { There are two accounts on behalf of the Regional Tax Office of East Java } \\
\text { III namely @ KanwilDJPJatim3 and @ kwldjpjatim3. Account } \\
\text { @ KanwilDJPJatim3 has 2,839 tweets, 788 following, 2,480 followers, and } \\
81 \text { likes. Next, account @ kwldjpjatim3 has } 889 \text { tweets, 222 following, } 645 \\
\text { followers, and } 177 \text { likes. } \\
\text { The content presented is simply a repost posting of Central Tax Office } \\
\text { accounts so it is less attractive to the followers as the readers. Preferably, } \\
\text { the content or post of the Twitter account of Regional Tax Office of East } \\
\text { Java III is based on its working area, informs the counseling activities that } \\
\text { will be carried out in the territory of the Regional Tax Office of East Java } \\
\text { III. }\end{array}$ \\
\hline $\begin{array}{l}\text { The description displayed on the profile page is not the same as the official } \\
\text { name of the Regional Tax Office of East Java III. } \\
\text { People appointed as tax ambassadors in the \#pajakbertutur are not } \\
\text { segmented. It is suggested that the selected tax ambassador is an inspiring } \\
\text { figure in the category of taxpayers who became the target of socialization. } \\
\text { The account @ kanwilpajakmalang has 611 posts, 1,460 followers, and 452 } \\
\text { following }\end{array}$
\end{tabular}

Source: Processed Data (2017) 
The table above shows that the social media used by the Regional Tax Office of East Java III for socialization includes twitter and instagram. There are two Twitter account on behalf of Regional Tax Office of East Java III namely@ @anwilDJPJatim3 that has been in operation since January 2015 with the number of followers of 2,480 twitter users, and the account@kwldjpjatim3 which has joined starting from March 2015 with the number of followers of 645 twitter users. However, both twitter accounts on the behalf of Regional Tax Office of East Java III can be categorized as not very active. Then, for social media Instagram, Regional Office of East Java III has an account @ kanwilpajakmalang which is quite lively. Instagram account of Regional Office of East Java III is quite active to provide posts related to the general knowledge of taxation. Analysis of all forms of socialization uses new media in Regional Office of East Java III.

In addition, twitter with a number of 2480 followers and 789 following is able to easy the information transaction. However, in fact, this twitter is stagnant in terms of the transactional information since it just retweets the tweets of the central and other tax offices is has not yet provided information to educate people about Individual Income Tax especially related to MSME including Government Regulation Number 46.

Next, the Official Instagram site of the Regional Tax Office of East Java III, 1459 followers, 451 following, and 611 posts. The number of followers has reached thousands, but the response from Instagram users is still low. Other visible indicator is the number of follower likes on every picture that is below 100 likes. Views on uploaded video has not reached 200 views. Feed shown is not wellordered so there is no clear distinction between giving information about paying taxes and events that has been held. Taxpayers will find it difficult to find specific information because the posts uploaded more focuses on activities which have been carried out, not information needed by taxpayers especially individual income tax in MSMEs. From the above discussion, it is known that the Regional Office of East Java III has several social media accounts in the form of Twitter, but the effectiveness of the account is not maximal and effective in conducting tax socialization. Convenience and ease that people feel is when socialization is carried out orally, formally and conventionally.

The socialization media of the Regional Tax Office of East Java III also utilizes official website and is merely centered on the National Directorate General of Taxation. The Regional Tax Office of East Java III does not have any website so that any form of information is centered on the National Tax Office so that the advantage is the information obtained will not be different because it is derived from one source only. However, the disadvantage is it would be difficult to map the segmentation and target the taxpayers.

Features that can be used by taxpayers on this website are Regional Tax Office online, efilling, Electronic Tax Payment Slip, Regional Tax Office online registration, Regional Tax Office online-login, and Agency. These features actually ease the tax payers in paying taxes accordingly and with timeliness. In the specific column of individual tax payer, there are options of free activities and employees. This will make it easier for individual taxpayers to pay taxes. At the bottom corner, there is a live chat feature to the staff of the tax office to ease the tax payers to ask for further information. Although the description obtained from the interview indicates that tax office website is the most visited government website, but the information transaction is still unremarkable.

c. Describing the Obstacles faced by Regional Tax Office of East Java III in the socialization of individual income tax on MSMEs in Malang The obstacles occurred on the socialization individual income tax on MSMEs in Malang because of data inconformity on the number of MSMEs due to the unavailable tax payer profiling, causing differences in understanding the meaning of the regulation as well as the perception. This occurs because of the different message that has not been conveyed; trust can also decrease associated with the attendance level of tax payers on the socialization held by the Regional Tax Office of East Java III.

The different MSMEs criteria are set out in Regulation Number 46 Year 2013 on MSME criteria according to relevant government institutions. This difference causes the regional tax office to only receive raw data presented by the related government institutions. This also causes the data provided by the relevant 
agencies to be not able to be directly synchronized with the MSME criteria as stipulated in Government Regulation Number 46 Year 2013. Inequality of this data makes the Regional Tax Office of East Java III to conduct similar socialization activities and cannot reach all MSMEs in Malang city based on the criteria of the Government Regulation Number 46 of 2013. Due to the absence of profiling MSME taxpayers, the socialization conducted by the Regional Tax Office of East Java III is for any participant and the material given is the same. Whereas the target of socialization of the regional office is aimed at improving the understanding of the participants of MSMEs on the tax but it not continued with further segmentation.

Furthermore, message or information delivered in the socialization process of individual income tax in Malang by the Regional Tax Office of East Java III is based on the Government Regulation Number 46 Year 2013. In delivering the information of government regulation number 46 Year 2013, the account representative of regional tax office also find difficulties in equating the perception to interpret government regulation due to the different respective viewpoints of the account representative. The intersection of taxation rules with other laws also become obstacles for the account representative in equating their interpretation of the Government Regulation Number 46 Year 2013. Inequality of interpretation point of view causes different delivery and incomplete socialization of the account representative of the Regional Tax Office.

Another important element in the socialization is the participants. In terms of taxation related to individual income tax of MSMEs, the regional tax office often finds it difficult to convince the whole participants to attend the socialization. Based on the statement of the Regional Tax Office of East Java III, the number of participants who attended the socialization activities very low compared with the invitations that have been delivered. The low attendance rate of socialization participants is due to the lack of trust and awareness of Taxpayers about taxation. This lack of trust is the impact of a pluralistic society with different backgrounds resulting in different perceptions of the importance of taxation.

Such constraints occur because of the current number of MSMEs in Malang is 226 from five districts comprising Blimbing, Kedungkandang, Klojen, and Sukun where the highest number of MSMEs is located in Kedungkandang District with a total number of 60 MSMEs and culinary business occupies the highest level. Table 2 presents data on MSME in Malang:

Table 2. Data of MSMEs in Malang City

\begin{tabular}{|c|c|c|c|c|c|}
\hline \multirow{2}{*}{ Districts } & \multicolumn{4}{|c|}{ Type of business } & \multirow{2}{*}{$\begin{array}{c}\text { Total } \\
\text { Num } \\
\text { ber }\end{array}$} \\
\hline & $\begin{array}{c}\text { Fashi } \\
\text { on }\end{array}$ & $\begin{array}{c}\text { Culin } \\
\text { ary }\end{array}$ & $\begin{array}{c}\text { Handic } \\
\text { raft }\end{array}$ & $\begin{array}{c}\mathrm{Et} \\
\mathrm{c}\end{array}$ & \\
\hline Blimbing & 5 & 27 & 10 & $\begin{array}{l}1 \\
5\end{array}$ & 57 \\
\hline $\begin{array}{l}\text { Kedungkan } \\
\text { dang }\end{array}$ & 11 & 26 & 4 & $\begin{array}{l}1 \\
9 \\
\end{array}$ & 60 \\
\hline Klojen & 5 & 24 & 12 & $\begin{array}{l}1 \\
2\end{array}$ & 53 \\
\hline Breadfruit & 7 & 23 & 6 & $\begin{array}{l}2 \\
0\end{array}$ & 56 \\
\hline Total & & & & & 226 \\
\hline
\end{tabular}

Based on the above table, it can be seen that the total number of MSMEs in Malang City is 266 MSMEs with an average of 45 MSMEs in each district. The types of MSME in the five districts of Malang city are in the field of fashion, culinary, handicraft and other types of businesses. The most dominating type of MSMEs business in Malang city is the culinary field. Kedungkandang district would be an interesting discussion because the distance of Kedungkandang is the furthest among the other three districts that is $8.4 \mathrm{~km}$. Thus, it takes a lot of effort to improve the public understanding and Individual Income Tax Payers. Secondly, the background of diverse human resources and inhomogeneous type of business as indicated by the culinary business but not all culinary business sell the exactly the same culinary. Thus, there is an error of information that occurs and non-compliance with Government Regulation Number 46. The non-compliance not only because the taxpayers are not willing to but the "don't know" answer also becomes the focus for the public relations division. The next section will explain how profiling conducted by the Regional Tax Office of East Java III so that data integration can be carried out later, namely by means of segmentation and target participant socialization of Individual Income Tax on MSMEs in Malang. It should be noted that this is one of the means for doing 
Social Marketing (Wang and Kim, 2017) (Alalwan, Rana, Dwivedi, Algharabal; 2017).

\section{DISCUSSION}

The findings of first research problem reveals that the Regional Tax Office of East Java III has not segmenting the target participants of the socialization of Individual Income Tax for MSMEs in Malang by profiling the tax payers one by one. Because the Regional Offices only classify the Taxpayer based on their income. This is understandable because of the schedule of the socialization held is the set by central tax office.

It is suggested to conduct an understanding between the profile-based and content-based (Zhu and Chen, 2015) where both can be carried out together in order to give a significant impact on the understanding of the taxpayers. Secondly, following the understanding of the profile-based and contentbased, the segmentation is further classified in accordance with the profile-based business owners, demographic age, sex, education (Jayaratne; Mort; D'Souza, 2017). Determining the participant of the socialization is by selecting the participants based on specific business type code that has been defined by the Central Government institutions. For instance, for culinary business MSMEs, the Regional Office of East Java III should invite all culinary MSMEs divided based on the district or in accordance with their lifespan. Thus, the quality of information that will be provided is appropriate and the taxpayers can respond the information provided. Because basically the two-way communication aimed at determining whether or not the level of understanding is the same. The word 'synergy' refers to the balance between society and government.

\section{CONCLUSION}

The Regional Tax Office of East Java III has been understood and carried out socialization to all taxpayers related to Government Regulation Number 46 , until conducting tax class. The strategy to hold the socialization has also cooperated with the related government institutions. Printed and online media have also been used. However, the making and use of social media advice through segmentation and target can be used as an alternative suggestion so that there is a synergy between the media and the conventional tax socialization. By considering that phenomenon, it is required to make a concrete step to maximize the potential existing in each region since the potential of technology-based taxation media in Malang area is quite high. Various forms of facilities in the tax office and the utilization of social media has been carried out for targeting the taxpayers. However, the lack of understanding of the people on the importance of using social media in socialization causes tax socialization to be choked or less effective. This is also the case in the MSME sector. The utilization of media technology is still quite low to form the synergy between media and government in the tax socialization. By monitoring every circulated information, it is necessary for the community and government to continuously improve the cooperation in this socialization activity.

The research findings can be further developed to some other topics about the deepening of the message content of socialization for taxpayers, designing learning patterns about the tax socialization, creating a blueprint for the efficiency of the communication system in the socialization of individual income tax on MSMEs or to generate more findings and advanced taxation communication. All of the above research topic suggestions are useful in supplementing information to help in educating Indonesians about taxes to make an active contribution to the country. Highlighting the latest concept illustrating the correlation between science communications with the tax system will create an effective and efficient pattern of social marketing. This understanding will certainly contribute positively and optimally, particularly in the development of science so that it can identify the problems that arise in the economy taxation world. It is undeniable that the concept of science communication, especially based on modern technology, is needed in this tax system. It is generally still at the embryo level to produce a blueprint in contributing to the effective tax dissemination for Indonesians.

\section{ACKNOWLEDGEMENT}

Thanks to Brawijaya University for granting us with the opportunity through the competition of Beginner Research Grant funds as well as to the Regional Tax Office of East Java III for sharing valuable information with the same spirit to help building a better country. 


\section{REFERENCES}

1. Berger, C. R., Roloff, M. E., \& Roskos, D. RThe Handbook of Communication Sciene.USA: Nusa Media. . (2015).

2. Kotler, P. \& Zaltman, G.Social marketing: an approach to planned social change. Journal of Marketing 35, 3-12. . (1971).

3. Kotler, P., \& Andreasen, A. Strategic marketing for nonprofit organizations (6th ed.). Prentice Hall. (2002)

4. Kotler, P., \& Roberto, E. L. Social marketing: Strategies for changing public behavior. New York: The Free Press Macmillan. (1989).

5. Keyton, Joanna. Communication Research Asking Questions,Finding Answers Second Edition. The Mc Graw-Hill Companies,Inc. New York. . 2006

6. Babbie, Earl. The Basics Social Research 6th Edition. Cengage Learning. Canada. 2014.

7. Creswell, John. Research Design Qualitative \& Quantitative Approaches. Sage Publication,Inc. State of America. 1994

8. Babbie, Earl. The Basics of Social Research Third Edition. Thompson Learning. 2005

9. Miles, Matthew B dan A.Michael Huberman. An Expanded Source Book Qualitative Data Analysis Second Edition. SAGE Publication, Inc. California. 1994.

10. Gay, L.R, G.E. Mills. Educational Research (Competencies for Analysis and Applications). USA: Pearson. (2006).

11. Altman, Daniel. Outrageous Fortunes: The twelve surprising trends that will reshape the global economy. Henry Holt and Company,LLC. New York. 2011.

12. Creswell, John W. Research Design Pendekatan Penelitian Kualitatif, Kuantitatif, dan Mixed. Yogyakarta: Pustaka Pelajar. Penterjemah Achmad Fawaid. 2014

13. Lefebvre, C. An integrative model for social marketing. Journal of Social Marketing, Vol. 1, Issue 1. (2011).

14. Landrum, et al.. Examining the Merits of Usefulness Versus Use in an Information Service Quality and Information System Success Web-Based Model. Information Resources. Management Journal, Volume 4, Issue 2. USA: IGI Publishing. 2008

15. Lofland, John; David Snow; Leon Anderson dan Lyn H.Lofland.. Analyzing Social
Seetings A Guide To Qualitative Observation and Analysis. Wadsworth/Thompson Learning. Belmont. 2006

16. Resmi, Siti.. Perpajakan Teori dan Kasus Edisi 9 buku 1. Salemba Empat. Jakarta Selatan. 2016

17. Singleton Jr, Royce A dan Bruce C Straits.. Approaches To Social Research Fourth Edition. Oxford University Press. New York. 2005

Miles, Matthew B dan A.Michael

Huberman. 1994. An Expanded Source

Book Qualitative Data Analysis Second Edition. SAGE Publication, Inc. California.

18. Arifin, Sjamsul; Rizal A. Djaafara dan Aida S. Budiman.. Masyarakat Ekonomi Asean 2015 : Memperkuat Sinergi ASean Di Tengah Kompetisi Global. PT. Elexmedia Compotindo Kelompok Kompas Gramedia. Jakarta. 2008

19. Arikunto, S.. Prosedur penelitian : Suatu Pendekatan Praktik. (Edisi Revisi). Jakarta : Rineka Cipta. 2010

\section{Online:}

Bisnis.radarmalang. 2017. Kepatuhan Wajib Pajak Belum 100\%.

http://bisnis.radarmalang.id/kepatuhan-wajibpajak-belum-100/ diunduh pada tanggal 19 Juni 2017 jam 13.50 PM.

Agus, Rustam. 2013. Peringkat Kemudahan Membayar Pajak Indonesia Anjlok. http://finansial.bisnis.com/read/20141130/10/2 76566/peringkat-kemudahan-membayarpajak-indonesia-anjlok diunduh pada tanggal 2 Mei 2017 jam 20.58 WIB.

Ariyanti, Fiki. 2016. Strategi Pemerintah Hindari Gelembung di Pasar keuangan. http://bisnis.liputan6.com/read/2560018/strate gi-pemerintah-hindari-gelembung-di-pasarkeuangan diunduh pada 1 Mei 2016 jam 16.33 WIB

Baskoro, Arya. 2013. Peluang, Tantangan dan Risiko Bagi Indonesia Dengan Adanya Masyarakat Ekonomi Asean. http://crmsindonesia.org/knowledge/crmsarticles/peluang-tantangan-dan-risiko-bagiindonesia-dengan-adanya-masyarakatekonomi diunduh pada tanggal 1 Mei 2017 jam 17.07 WIB. 
.Djumena, Erlangga. 2010. Waspadai Gelembung Keuangan.

http://lifestyle.kompas.com/read/2010/10/04/0 7344730/waspadai.gelembung.keuangan diunduh pada 1 Mei 2017 jam 16.01 WIB.

Hasan, Iqbal. 2002. Pokok-Pokok Materi Metodologi Penelitian dan Aplikasinya. Jakarta : Ghalia Indonesia.

International Monetary Fund. 2017. World Economic Outlook Update: A Shifting Global Economic Landscape.

https://www.imf.org/external/pubs/ft/weo/201

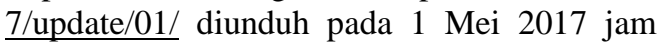
17.04 WIB.
Kementerian Keuangan RI. 2014. www.kemenkeu.go.id diakses pada 1 Mei 2017.

Kementerian Keuangan RI. 2017. Laporan Realisasi Anggaran Pendapatan Negara. www.kemenkeu.go.id diakses pada 1 Mei 2017. 